Eur. J. Clin. Chem. Clin. Biochem.

Vol. 32, 1994, pp. 449-453

() 1994 Walter de Gruyter \& Co. Berlin - New York

\title{
The Effect of Two Regimens of Hormone Replacement Therapy on the Haemostatic Profile in Postmenopausal Women
}

\author{
By J.W. J. van Wersch ${ }^{1}, J . M . H$. Ubachs ${ }^{2}, A$. van den Ende ${ }^{3}$, and $A$. van Enk ${ }^{4}$ \\ ${ }^{1}$ Department of Haematology, De Wever Hospital, Heerlen, The Netherlands \\ 2 Department of Gynaecology, De Wever Hospital, Heerlen, The Netherlands \\ 3 Department of Clinical Chemistry, Slotervaart Hospital, Amsterdam, The Netherlands \\ 4 Department of Gynaecology, Slotervaart Hospital, Amsterdam, The Netherlands
}

(Received January 17/March 9, 1994)

Summary: The effect of two different regimens of hormone replacement therapy on coagulation and fibrinolysis was measured in 30 women taking Tibolone (Livial ${ }^{\circledR}$ ) and 30 taking oestradiol valerate, sequentially combined with cyproterone acetate (Climen ${ }^{\circledR}$ ). Blood samples were taken before the beginning of the medication, then six and twelve months afterwards. The Livial ${ }^{\circledR}$ group showed a rise of fibrinolytic activity as measured by the $\alpha_{2}$-antiplasmin-plasmin complexes. Tissue plasminogen activator antigen and plasminogen activator inhibitor-1 decreased simultaneously. No effect was seen in the coagulation variables. In the Climen ${ }^{\circledR}$ group no significant alterations were noticed, either in the coagulation or in the fibrinolysis variables. In the direct comparison of both substances only factor VII appeared to be significantly higher in the Climen ${ }^{\circledR}$ group after six months and one year of treatment.

\section{Introduction}

Hormonal replacement therapy has attracted increasing interest in recent decades. It is now used by a substantial number of women to overcome the various complaints of the menopause. In cases of an intact uterus, preparations are used in which the oestrogen component is either sequentially or continuously combined with a progestagen to prevent pharmaceutically induced endometrial hyperplasia and/or carcinoma $(1,2)$. Oestrogens have a vasodilatatory effect and influence the serum lipid concentrations favourably (3-5). Because lipids and haemostasis are linked (6-9), it is of interest to study the haemostatic effects of hormonal replacement therapy. Oestrogens have been reported to enhance the plasma concentrations of several coagulation factors (fibrinogen, F II, VII, VIII:c, LX, X and XII) and the fibrinolysis factor plasminogen $(10-13)$, whereas antithrombin III was shown to be diminished $(12,14)$.

The progestagens administered in hormonal replacement therapy are either nortestosterone or progesterone derivates. The effect of progestagens on serum lipid concen- trations can be summarized as an increase in total cholesterol and LDL-cholesterol, and a decrease in HDLcholesterol and triacylglycerols (15), whereas progesterone derivatives appear to have no effect on these quantities. Effects on haemostasis are not well documented. Both an increase and decrease of fibrinogen have been described during the normal cycle $(16,17)$. In general, however, a significant influence on the haemostatic system is not to be expected.

In this study the effect of two different regimens on the haemostatic profile was measured. Tibolone (Livial ${ }^{\circledR}$ ), a synthetic steroid with oestrogenic, progestogenic and androgenic-anabolic properties, was given in a dose of $2.5 \mathrm{mg}$ daily. This regimen was compared with the administration of $2 \mathrm{mg}$ oestradiol valerate, which is immediately metabolized to the natural human oestrogen, oestradiol, and combined in the last 10 days of the cycle with $1 \mathrm{mg}$ cyproterone acetate $\left(\right.$ Climen $\left.^{\circledR}\right)$.

Cyproterone acetate is a 17-hydroxyprogesterone derivative with progestogenic and anti-androgenic properties. Long-term cyclic treatment with cyproterone ace- 
Tab. 1. Comparison of the median values (25th -75 th percentiles) of various coagulation quantities at different stages of the Livial ${ }^{\otimes}$ and the Climen ${ }^{\circledR}$ treatment ( $\mathrm{A}=$ at start; $\mathrm{B}=$ after 6 months; $\mathrm{C}=$ after 12 months).

\begin{tabular}{|c|c|c|c|c|c|c|}
\hline & & \multicolumn{4}{|c|}{ Patients group } & \multirow{2}{*}{$\begin{array}{l}\text { Significance* } \\
\text { p-value }\end{array}$} \\
\hline & & $\begin{array}{l}\text { Livial }^{\circledR} \\
\text { median } \\
(25 \text { th }- \\
\text { percenti }\end{array}$ & $\begin{array}{l}\text { (8) } \\
\text { n } \\
-75 \text { th } \\
\text { tiles) }\end{array}$ & $\begin{array}{l}\text { Climen }^{\circledR} \\
\text { median } \\
(25 \text { th-75 } \\
\text { percentile }\end{array}$ & th & \\
\hline Fibrinogen $(g / l)$ & $\begin{array}{l}\text { A } \\
\text { B } \\
\text { C }\end{array}$ & $\begin{array}{c}3.6 \\
(3.3- \\
3.6 \\
(3.3- \\
3.6 \\
(3.4-\end{array}$ & $\begin{array}{l}-\quad 4.2) \\
-\quad 3.9) \\
-\quad 4.5)\end{array}$ & $\begin{array}{c}3.7 \\
(3.5- \\
3.6 \\
(3.3- \\
3.6 \\
(3.2-\end{array}$ & $\begin{array}{l}4.0) \\
4.0) \\
4.0)\end{array}$ & $\begin{array}{l}\text { n.s. } \\
\text { n.s. } \\
\text { n.s. }\end{array}$ \\
\hline Factor VII (\%) & $\begin{array}{l}\text { A } \\
\text { B } \\
\text { C }\end{array}$ & $\begin{array}{rr}90 & \\
(79 & - \\
85 & \\
(78 & - \\
84 & \\
(75 & -\end{array}$ & $\begin{array}{l}-114) \\
-98) \\
-111)\end{array}$ & $\begin{array}{rr}97 & \\
(87 & -1 \\
117 & \\
(93 & -1 \\
113 & \\
(83 & -1\end{array}$ & $\begin{array}{l}\text { 09) } \\
\text { 30) } \\
\text { 32) }\end{array}$ & $\begin{array}{l}\text { n.s. } \\
0.004 \\
\text { n.s. }\end{array}$ \\
\hline $\begin{array}{c}\text { Thrombin-antithrombin III }(\mu \mathrm{g} / \mathrm{l}) \\
\therefore i\end{array}$ & $\begin{array}{l}\text { A } \\
\text { B } \\
\text { C }\end{array}$ & $\begin{array}{c}2.3 \\
(2.0- \\
2.3 \\
(2.0- \\
2.3 \\
(1.9-\end{array}$ & $\begin{array}{l}-\quad 3.2) \\
-\quad 2.7) \\
-\quad 3.3)\end{array}$ & $\begin{array}{c}2.1 \\
(1.7- \\
2.1 \\
(1.9- \\
2.0 \\
(1.7-\end{array}$ & $\begin{array}{l}3.2) \\
3.1) \\
2.2)\end{array}$ & $\begin{array}{l}\text { n.s. } \\
\text { n.s. } \\
\text { n.s. }\end{array}$ \\
\hline Prothrombin fragment $1+2(\mathrm{nmol} / \mathrm{l})$ & $\begin{array}{l}\text { A } \\
\text { B }\end{array}$ & $\begin{array}{c}1.10 \\
(0.84- \\
1.09 \\
(0.95- \\
1.20 \\
(0.96-\end{array}$ & $\begin{array}{l}1.35) \\
1.28) \\
1.40)\end{array}$ & $\begin{array}{l}0.95 \\
(0.81- \\
1.08 \\
(0.82- \\
1.14 \\
(0.91-\end{array}$ & $\begin{array}{l}1.53) \\
1.37) \\
1.40)\end{array}$ & $\begin{array}{l}\text { n.s. } \\
\text { n.s. } \\
\text { n.s. }\end{array}$ \\
\hline
\end{tabular}

* Mann-Whitney-U test

tate given in the mentioned dose has no effect on the lipid metabolism (18). Livial ${ }^{\circledR}$ is known to lower fibrinogen and factors VII and VIII $(19,20)$, and to increase antithrombin III (21); enhanced fibrinolytic activity has been reported $(19,20)$. In the present study the haemostatic effects of Livial ${ }^{\circledR}$ and Climen ${ }^{\circledR}$ were compared. The essential difference between the two preparations is the presence and absence, respectively, of androgenic-anabolic properties.

\section{Methods}

\section{Coagulation measurements}

Fibrinogen was measured with a clotting assay (Merz and Dade) according to the method of Clauss, by means of a Schnittger \& Gross coagulometer. F VII concentrations were assessed with an amidolytic test kit of Kabi Vitrum Diagnostica (Mölndal, Sweden). The prothrombin fragment $1+2$ test was determined with an ELISA test kit (Behring Corporation, Marburg, Germany). For the thrombin-antithrombin III determination an ELISA test kit (Behring Corporation, Marburg, Germany) was used.

\section{Fibrinolysis measurements}

The D-dimer fibrin degradation products were measured by means of the FbDP test (Organon Technika, Boxtel, The Netherlands). The
FbDP is a specific ELISA test for the determination of degradation products of cross-linked fibrin only, and not of fibrinogen. For tissue plasminogen activator antigen and plasminogen activator inhibitor-1, ELISA test kits from Innogenetics (Antwerp, Belgium) were used. The $\alpha_{2}$-antiplasmin-plasmin complex determinations were from Behring Corporation (Marburg, Germany).

\section{Samples}

Blood samples were drawn in citrate-containing plastic tubes after fasting overnight between 8.30 and $9.30 \mathrm{a}$. m. and a resting period of $20 \mathrm{~min}$ before venipuncture. Alcohol was not allowed the previous day. The analysis was conducted in citrated plasma prepared by centrifugation of nine volumes freshly collected blood with one volume trisodium citrate $(0.11 \mathrm{~mol} / \mathrm{l})$ for $10 \mathrm{~min}(1600 \mathrm{~g})$ at $25^{\circ} \mathrm{C}$. The plasma was stored at $-70^{\circ} \mathrm{C}$ in plastic tubes and thawed with tap water of $37^{\circ} \mathrm{C}$ for $5 \mathrm{~min}$ before serial analysis.

\section{Trial design}

Sixty healthy women with menopausal complaints, in the age group of 45-55, and between $1-5$ years after the menopause were admitted to an open randomized, comparative clinical trial over 12 treatment cycles. Their body weight was within standard weight $\pm 10 \%$ (22). Women with a history of drugs, smoking more than 10 cigarettes per day and/or drinking more than $40 \mathrm{ml}$ of alcohol per day were excluded from the study. They took no preparations which might influence lipids. Two menopausal centres participated and each centre included 30 women. Randomization was conducted in blocks of 30 . Each group used either Livial or Climen ${ }^{(2)}$ con- 
tinuously for 12 months. Livial ${ }^{\oplus}$ (Tibolone) was given in a dosage of $2.5 \mathrm{mg}$ daily, without a tablet-free interval. The Climen ${ }^{\circledR}$ regimen consisted of 21 tablets containing $2 \mathrm{mg}$ of oestradiol valerate with the last 10 tables containing additionally $1 \mathrm{mg}$ cyproterone acetate and a 7-day tablet-free interval between every cycle. Medication was taken at about the same time in the evening. Blood samples were taken before the start of the medication and between cycle days 18-21 of treatment cycles 6 and 12 .

\section{Statistics}

The significance of the differences was assessed by the Mann-Whitney $\mathrm{U}$ test (level of significance $\mathrm{p}=0.05$ ).

The significance of the trends of the various analytes during the two treatment options was computed by the Kruskal-Wallis test (significance level $\mathrm{p}=0.05$ ).

\section{Results}

In table 1 the comparison of the median values (2575 percentiles) of the various coagulation quantities at different stages of Livial ${ }^{\circledR}$ and Climen ${ }^{\circledR}$ treatment are given. The only quantity showing a statistically signifi- cant difference in concentration between the Livial ${ }^{\circledR}$ and Climen groups six months after the start was factor VII, although there was still no significant trend after one year of treatment. The results of the fibrinolysis quantities show more significances when compared at the different stages of treatment (tab. 2).

Tissue plasminogen activator concentrations were significantly lower in the Livial ${ }^{\circledR}$ than in the Climen ${ }^{\circledR}$ group both after six months and after one year of treatment. Parallel behaviour was seen for plasminogen activator inhibitor-1 at the same stages of medication. The Livial ${ }^{\circledR}$ group showed higher values for $\alpha_{2}$-antiplasminplasmin complex after six and twelve months of treatment. The various coagulation and fibrinolysis quantities during Livial ${ }^{\circledR}$ and Climen ${ }^{\circledR}$ treatment were compared (at start, after 6 and 12 months), using the KruskalWallis test. In the coagulation series, no trend was found in the course of one year of treatment with Climen ${ }^{\circledR}$. With Livial ${ }^{\circledR}$ there were significant decreasing trends for tissue plasminogen activator $(p=0.01)$ and plas-

Tab. 2. Comparison of the median values (25th-75th percentiles) of various fibrinolysis quantities at different stages of the Livial ${ }^{\circledR}$ and the Climen ${ }^{\circledR}$ treatment

$(\mathrm{A}=$ at start; $\mathrm{B}=$ after 6 months; $\mathrm{c}=$ after 12 months).

\begin{tabular}{|c|c|c|c|c|}
\hline & & \multicolumn{2}{|l|}{ Patients group } & \multirow{2}{*}{$\begin{array}{l}\text { Significance* } \\
\text { p-value }\end{array}$} \\
\hline & & $\begin{array}{l}\text { Livial }^{\circledR} \\
\text { median } \\
\text { (25th-75th } \\
\text { percentiles) }\end{array}$ & $\begin{array}{l}\text { Climen }^{\circledR} \\
\text { median } \\
\text { (25th-75th } \\
\text { percentiles) }\end{array}$ & \\
\hline Tissue plasminogen activator $(\mu \mathrm{g} / \mathrm{l})$ & $\begin{array}{l}\text { A } \\
\text { B } \\
\text { C }\end{array}$ & $\begin{array}{cc}\left.4.5^{1}\right) & \\
(3.1- & 5.8) \\
\left.3.0^{1}\right) & \\
(2.3- & 4.2) \\
\left.3.5^{1}\right) & \\
(1.9- & 4.9)\end{array}$ & $\begin{array}{cc}4.4 & \\
(3.7- & 5.7) \\
4.7 & \\
(3.5- & 5.8) \\
4.6 & \\
(3.5- & 5.6)\end{array}$ & $\begin{array}{l}\text { n.s. } \\
0.004 \\
0.042\end{array}$ \\
\hline Plasminogen activator inhibitor-1 $(\mu \mathrm{g} / \mathrm{l})$ & $\begin{array}{l}\text { A } \\
\dot{\mathrm{B}} \\
\mathrm{C}\end{array}$ & $\begin{array}{l}\left.68^{2}\right) \\
(46-91) \\
\left.47^{2}\right) \\
(37-62) \\
\left.39^{2}\right) \\
(29-64)\end{array}$ & $\begin{array}{rr}70 & \\
(48 & -106) \\
73 & \\
(41 & -103) \\
62 & \\
(44 & -80)\end{array}$ & $\begin{array}{l}\text { n.s. } \\
0.02 \\
0.02\end{array}$ \\
\hline D-dimer $(\mu \mathrm{g} / \mathrm{l})$ & $\begin{array}{l}\text { A } \\
\text { B } \\
\text { C }\end{array}$ & $\begin{array}{rr}240 & \\
(200 & -360) \\
240 & \\
(190 & -350) \\
240 & \\
(185 & -320)\end{array}$ & $\begin{array}{cc}250 & \\
(190 & -360) \\
250 & \\
(190 & -330) \\
233 & \\
(170 & -340)\end{array}$ & $\begin{array}{l}\text { n.s. } \\
\text { n.s. } \\
\text { n.s. }\end{array}$ \\
\hline$\alpha_{2}$-Antiplasmin-plasmin complex $(\mu \mathrm{g} / \mathrm{l})$ & $\begin{array}{l}\text { A } \\
\text { B } \\
\text { C }\end{array}$ & $\begin{array}{l}\left.290^{3}\right) \\
(195-400) \\
\left.425^{3}\right) \\
(365-660) \\
\left.435^{3}\right) \\
(330-650)\end{array}$ & $\begin{array}{cc}250 & \\
(183 & -380) \\
260 & \\
(200 & -335) \\
238 & \\
(185 & -335)\end{array}$ & $\begin{aligned} \text { n.s. } \\
<0.001 \\
<0.001\end{aligned}$ \\
\hline
\end{tabular}

\footnotetext{
* Mann-Whitney-U test

1) Kruskal-Wallis test $\mathrm{A} / \mathrm{B} / \mathrm{C}, \mathrm{p}=0.01$

2) Kruskal-Wallis test $\mathrm{A} / \mathrm{B} / \mathrm{C}, \mathrm{p}=0.005$

3) Kruskal-Wallis test $\mathrm{A} / \mathrm{B} / \mathrm{C}, \mathrm{p}=0.005$
} 
minogen activator inhibitor-1 $(p=0.005)$ and a significant increase for $\alpha_{2}$-antiplasmin-plasmin complex $(p=0.0005)$.

\section{Discussion}

Coagulation and fibrinolysis were studied during a one year treatment of postmenopausal women with Livial ${ }^{\circledR}$ or Climen ${ }^{\circledR}$, to investigate the influence of this medication on the haemostatic profile, and to establish potential differences in coagulation and fibrinolysis at start and after six and twelve months of treatment. The two substances differ considerably in their chemical composition and pharmacological mechanisms. As androgenicanabolic substances are known to influence the fibrinolytic system, it might be expected that the administration of Livial ${ }^{\circledR}$, which has an androgen-anabolic component, would give rise to changes in the concentrations of fibrinolysis markers $(23-25)$. This is confirmed by the changes in the fibrinolysis markers, tissue plasminogen activator, plasminogen activator inhibitor- 1 and $\alpha_{2}$ antiplasmin-plasmin complex and the consistency of the coagulation quantities. During the Climen ${ }^{\circledR}$ medication no influence on the studied coagulation and fibrinolysis markers was found. Evaluation of the results of both regimens confirms therefore the indifferent behaviour of Climen $^{\circledR}$ in this respect. Livial ${ }^{\circledR}$ medication induced an enhancement of $\alpha_{2}$-antiplasmin-plasmin complex, which is indicative of an activation of the fibrinolysis system.

In general this effect might be considered to be advantageous. It is in line with previous studies $(19,20)$ which also reported a stimulation of the fibrinolysis by Livial ${ }^{\circledR}$, although less sensitive methods were used $(19,20)$. Earlier studies, indicating that Livial ${ }^{\circledR}$ lowers the level of factor VII and of fibrinogen, were not confirmed. It could only be demonstrated that at the two stages of treatment the factor VII concentrations were lower in the Livial ${ }^{\circledR}$ group than in the Climen ${ }^{\circledR}$ group.

In conclusion, both medications are indifferent to the coagulation system. Climen ${ }^{\circledR}$ is indifferent to the fibrinolysis system, whereas the Livial ${ }^{\circledR}$ regimen gave rise to a stimulated fibrinolytic activity, of which the clinical significance is still unclear.

\section{Acknowledgement}

We wish to thank the group of general practitioners of Dr. van Enk in Amsterdam for their cooperation.

The authors are also grateful to Miss Melanie Lennarts for her excellent technical assistance and to Miss Petra Hawinkels for typing the manuscript.

\section{References}

1. Sarrel, P. M. (1988) Estrogen replacement therapy. Obstet. Gynaecol. 72, 2S-5S.

2. Sherwin, B. B. \& Gelfand, M. M. (1985) Differential symptom response to parenteral estrogen and/or androgen administration in the surgical menopause. Am. J. Obstet. Gynecol. 151, $153-160$.

3. Lobo, R. A. (1991) Effects of hormonal replacement on lipids and lipoproteins in postmenopausal women. J. Clin. Endocrinol. Metab. 73 , 925-930.

4. Rijpkema, A. H. M., van der Sanden, A. A. \& Ruijs, A. H. C. (1990) Effects of postmenopausal oestrogen-progestogen replacement therapy on serum lipids and lipoproteins: A review. Maturitas 12, 259-285.

5. van der Mooren, M. J., Demacker, P. N. M., Thomas, C. M. G. \& Rolland, R. (1992) Beneficial effects on serum lipoproteins by $17 \beta$-oestradiol-dydrogesterone therapy in postmenopausal women: a prospective study. Eur. J. Obstetrics \& Gynaecology and Reproductive Biology 47, 153-160.

6. Simpson, H. C., Mann, J. I. \& Meade, T. W. (1983) Hypertriglyceridemia and hypercoagulability. Lancet $I, 786-790$.

7. Skartlien, A. H., Lyberg-Beckmann, S., Holme, I., Hjermann, I. \& Prydz, H. (1989) Effect of alteration in triglyceride levels on factor VII-phospholipid complexes in plasma. Arteriosclerosis $9,798-801$.

8. Elkeles, R. S., Chakrabarti, R., Vickers, M., Stirling, Y. \& Meade, T. W. (1980) Effect of treatment of hyperlipidaemia on haemostatic variables. Br. Med. J. 281, 973-974.

9. Nordoy, A., Illingworth, D. R., Connor, W. E. \& Goodnight, S. Jr. (1989) Increased activity of factor VII and factor VIIphospholipid complex measured using a Normotest system in subjects with hyperlipidemia. Haemostasis $19,65-72$.

10. Chetkowski, R. J., Meldrum, D. R. \& Steingold, K. A. (1986) Biologic effects of transdermal estradiol. N. Engl. J. Med. 314, 1615-1620.

11. Hamilton, P. J., Allardyce, M. \& Ogston, D. (1974) The effect of age on the coagulation system. J. Clin. Pathol. 27, 980982.

12. Notelovitz, M. (1977) Coagulation, estrogen, and the menopause. Clin. Obstet. Gynecol. 4, $107 \dot{7}-128$.

13. Notelovitz, M., Kitchens, C., Ware, M., Hirschberg, K. \& Coone, L. (1983) Combination estrogen and progestogen replacement therapy does not adversely affect coagulation. Gynaecol. $62,596-600$.

14. Notelovitz, M., Kitchens, C. S., Rappaport, V., Coone; L. \& Dougherty, M. (1981) Menopausal status associated with increased inhibition of blood coagulation. Am. J. Obstet. Gynecol. $141,149-152$.

15. Silfverstolpe, G., Gustafson, A., Samsioe, G. \& Svanborg, A. (1979) Lipid metabolic studies in oophorectomized women. Effects of three different progesterogens. Acta Obstet. Gynecol. Scand. 88, 89-95.

16. Lebech, A. M., Kjaer, A. \& Lebech, P. E. (1990) Metabolic changes during the normal menstrual cycle: A longitudinal study. Am. J. Obstet. Gynecol. 163, no 1 II: 414-416.

17. Siegbahn, A., Odlind, V., Hedner, U. \& Venge, P. (1989) Coagulation and fibrinolysis during the normal menstrual cycle. Ups. J. Med. Sci. 94, 137-152.

18. Jensen, J., Rìis, B. J. \& Christiansen, C. (1987) Cyproterone acetate, an alternative progestogen in post menopausal hormone replacement therapy? Effects on serum lipids and lipoproteins. Br. J. Obstet. Gynaecol. 94, 138-141.

19. Walker, I. D., Davidson, J. F.; Richards, A., Yatës, R. \& McEwan, H. P. (1985) The effect of the synthetic steroid Org 
OD 14 on fibrinolysis and blood lipids in postmenopausal women. Thromb. Haemost. 53, 303-305.

20. Cortes-Prieto, J. (1987) Coagulation and fibrinolysis in postmenopausal women treated with Org OD 14. Maturitas l, 67-73.

21. Parkin, D. E., Smith, D., Al Azzawi, F., Lindsay, R. \& Hart, D. M. (1987) Effect of long-.term Org OD 14 administration on blood coagulation in climacteric women. Maturitas 9, 95-101.

22. Jeliffe, D. B. (1966) The Assessment of the Nutritional Status of the Community. World Health Organization, Monography Series 53, 3-271.

23. Kluft, C., Preston, F. E., Malia, R. G., Bertina, R. M., Wijngaards, G., Greaves, M., Verheijen, J. H. \& Dooijewaard, G. (1984) Stanozolol-induced changes in fibrinolysis and coagulation in healthy adults. Thromb. Haemostas. 51, 157-164.
24. Manucci, P. M., Kluft, C., Traas, D. W., Seveso, P. \& D'Angelo, A. (1986) Congenital plasminogen deficiency associated with venous thromboembolism: therapeutic trial with stanozolol. Br. J. Haematol. 63, 753-759.

25. Shigekiyo, T., Tomonari, A., Uno, Y. \& Kishi, Y. (1992) Danazol therapy in hypoplasminogenemia. Thromb. Haemostas. 68.(2); 233-234.

Dr. J. W. J. van Wersch

Haematological Laboratory

De Wever Hospital

P. O. Box 4446

6401 CX Heerlen

The Netherlands 
